\title{
Two Antioxidative Diterpenes from Rosemary (Rosmarinus officinalis L.) and a Revised Structure for Rosmanol ${ }^{\dagger}$
}

\author{
Nobuji NAKATANI and Reiko INATANI \\ Department of Food and Nutrition, Faculty of Science of Living, \\ Osaka City University, Sumiyoshi-ku, Osaka 558, Japan \\ Received February 6, 1984
}

\begin{abstract}
Two new antioxidative compounds, named epirosmanol (4a) and isorosmanol (6a), were isolated from the leaves of rosemary (Rosmarinus officinalis L.). The structures have been

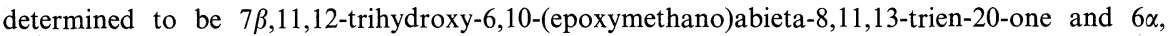
11,12-trihydroxy-7,10-(epoxymethano)abieta-8,11,13-trien-20-one, respectively, on the basis of chemical and spectroscopic evidence. Both are isomers of rosmanol (1a), whose structure was revised to be $7 \alpha, 11,12$-trihydroxy-6,10-(epoxymethano)abieta-8,11,13-trien-20-one by the NOE experiment and X-ray analysis.

These two antioxidants showed high activity in both lard and linoleic acid and, particularly in lard, were about four times more active than such synthetic antioxidants, as BHA and BHT.
\end{abstract}

In the course of our investigation on natural antioxidants, two new active compounds were isolated from rosemary (Rosmarinus officinalis L.), one of the herb spices belonging to the Family Labiatae. We have previously reported two diterpene lactones, rosmanol (1a), ${ }^{1 \sim 3)}$ which shows more remarkable an antioxidative activity than carnosol (2), and rosmadial (3) ${ }^{4}{ }^{4}$ from the same plant. This is part of a world wide trend to find new and safe antioxidants occurring naturally. ${ }^{5 \sim 10)}$

In this paper, we describe the structural determination of these additional antioxidative compounds.

The active fraction of the weakly acidic components from rosemary was purified as mentioned in previous papers. ${ }^{2,4)}$ Repeated chromatography on silica gel of the more polar fraction than rosmanol afforded a scarcely soluble compound, named epirosmanol (4a), which recrystallized from acetone to give prisms, $\mathrm{mp} 221.5^{\circ} \mathrm{C}$. Elementary analysis and MS indicated the molecular formula to be $\mathrm{C}_{20} \mathrm{H}_{26} \mathrm{O}_{5}$, which is the same with that of rosmanol. The UV and IR spectra of $\mathbf{4 a}$ are characteristically similar in respect to those of 1a. Absorption bands at 3500 and $3350 \mathrm{~cm}^{-1}$ in the IR spectrum were attributed to hydroxyl groups, and a band at $1758 \mathrm{~cm}^{-1}$ to a $\gamma$-lactone group. The UV absorption showed $\lambda_{\max }$ at 206, 228 and $290 \mathrm{~nm}$.

In the spectrum of ${ }^{1} \mathrm{H}-\mathrm{NMR}$, two singlets at $\delta 0.90(3 \mathrm{H})$ and $1.04(3 \mathrm{H})$ were attributed to the geminal dimethyl groups, C-19 $(\beta)$ and C$18(\alpha)$, respectively. A doublet at $\delta 1.17(6 \mathrm{H}$, $J=7.2 \mathrm{~Hz}$ ) and a septet, overlapped with $1 \mathrm{H}$ of C-1 $(\beta)$, at $\delta 3.30(1 \mathrm{H}, J=7.2 \mathrm{~Hz})$ were assigned to dimethyl and methine protons, respectively, of the isopropyl group attached to an aromatic ring. Conspicuous spectral differences between 4a and rosmanol (1a) were the appearance of a singlet of the C-5 proton at $\delta 2.00$ instead at 2.29 in the case of rosmanol, and signals at $\delta 4.72$ as a broad singlet $(2 \mathrm{H})$ and at $7.05(1 \mathrm{H})$ as a singlet due to the protons of C-6 and C-7, and the aromatic ring, respectively.

This data suggested the new compound (4a) to be an isomer on the B-ring of rosmanol. Acetylation of $\mathbf{4 a}$ with acetic anhydride and

$\dagger$ Constituents of Spices of the Family Labiatae. Part III. This study was presented at the Annual Meeting of the Agricultural Chemical Society of Japan, Sendai, April 1983. For Part II, see ref. 4. 


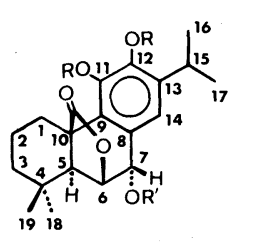

1a $R, R^{\prime}=H$

1b $R, R^{\prime}=A C$

1C $R=M e, R^{\prime}=H$

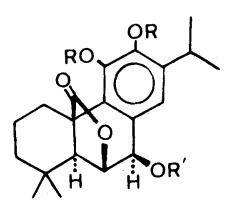

$\begin{array}{ll}\text { 4a } & R, R^{\prime}=H \\ 4 b & R, R^{\prime}=A C \\ 4 C & R=M e, R^{\prime}=H\end{array}$

pyridine afforded a triacetyl derivative $(\mathbf{4 b}$, $\mathrm{C}_{26} \mathrm{H}_{32} \mathrm{O}_{8}$ ), $m / z$ 472. In the IR spectrum, hydroxyl groups disappeared, while a new absorption band of acetate was observed at $1770 \mathrm{~cm}^{-1}$. Three singlets of acetyl groups at $\delta 2.20,2.28$ and 2.31 in the ${ }^{1} \mathrm{H}-\mathrm{NMR}$ spectrum supported the presence of three hydroxyl groups in the structure of $\mathbf{4 a}$. By the acetylation, an overlapped broad signal $(2 \mathrm{H})$ observed at $\delta 4.72$ in 4 a separated and shifted lower to $\delta 4.88$ and 5.61 , as an apparent doublet and a doublet, respectively, with the same coupling constant of $4.3 \mathrm{~Hz}$. The former was assigned to the C-6 proton and the latter to the C-7 proton. To confirm the attached position of the hydroxyl group, 4a was methylated with methyl iodide and potassium carbonate to give a phenolic dimethyl ether (4c), whose two methyl signals appeared at $\delta 3.80$ and 3.82. The remaining alcoholic hydroxyl group of $\mathbf{4 c}$ was oxidized with active manganese dioxide to give a keto lactone (5), $\mathrm{C}_{22} \mathrm{H}_{28} \mathrm{O}_{5}, \mathrm{M}^{+} m / z$ 372. This keto lactone dimethy1 ether was identical in all respects with that derived from rosmanol via 1c. ${ }^{2)}$ Reduction of 5 with $\mathrm{NaBH}_{4}$ in methanol<smiles>CC(C)c1cc(O)c(C23CCCC(C)(C)[C@H]2COC3O)c(O)c1O</smiles>

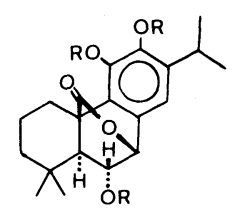

$\begin{array}{ll}6 a & R=H \\ 6 b & R=A C\end{array}$ gave two isomers $1 c$ and $\mathbf{4 c}$ at a ratio of 15 to 85. These results confirmed the position of the hydroxyl group on C-7, and revealed the new compound to be an epimer of rosmanol.

To clarify the configuration of C-7, an NOE experiment was run on triacetyl epirosmanol. When $\mathrm{H}-5$ at $\delta 2.08$ was irradiated, NOE was observed with $\mathrm{H}-7$ as high as $13 \%$. This supported 1,3-diaxial relationship between $\mathrm{H}-5$ and $\mathrm{H}-7$, with $\mathrm{H}-7$ be in the $\alpha$-configuration and the hydroxyl group at C-7 as $\beta$. This $\beta$ configuration of the hydroxyl group at $\mathrm{C}-7$ was previously assigned for rosmanol from the data of a differential NOE experiment. ${ }^{1,2)}$ To resolve the discrepancy between these two experiments, triacetyl rosmanol was reinvestigated with a more precise NOE determination and only $3 \%$ NOE was observed between $\mathrm{H}-5$ and $\mathrm{H}-7$. From this evidence, we propose the revised structure 1a for rosmanol and $\mathbf{4 a}$ for the new compound, epirosmanol.

As shown in Fig. 1, an X-ray crystal analysis on triacetyl rosmanol (1b) also confirmed the stereochemistry of C-5, C-6, C-7 and C-10. Colorless single crystals of $\mathbf{1 b}\left(\mathrm{C}_{26} \mathrm{H}_{32} \mathrm{O}_{8}\right)$ were 

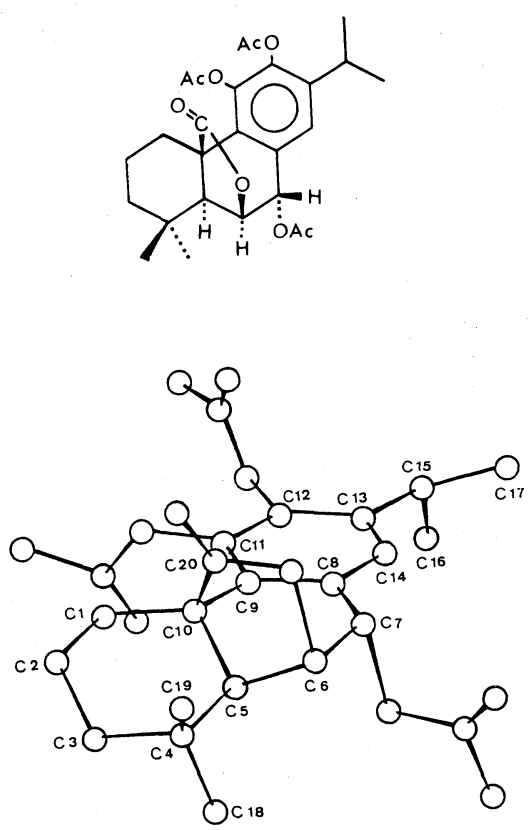

FIG. 1. X-Ray Stereoscopic View of Triacetyl Rosmanol.

recrystallized from benzene- $n$-hexane, mp $218^{\circ} \mathrm{C}$. The crystal data were as follows: monoclinic; space group $\mathrm{P} 2_{1} ; \mathrm{a}=10.655$ (8), $\mathrm{b}=11.029$ (6), $\mathrm{c}=11.527$ (6) $\AA ; \beta=110.20$ $(5)^{\circ}, Z=2$.

All this evidence established the structure 1a, 7 7,11,12-trihydroxy-6,10-(epoxymethano)abieta-8,11,13-trien-20-one, for rosmanol and 7-epimer $(\beta$-hydroxy,4a) for the new antioxidant, epirosmanol.

Another antioxidative compound (6a) was purified by Sephadex LH-20 to give colorless crystals, mp $227.0^{\circ} \mathrm{C}$. The molecular formula was determined to be $\mathrm{C}_{20} \mathrm{H}_{26} \mathrm{O}_{5}$, also one of the isomers of rosmanol. This compound was named isorosmanol. The IR spectrum of $\mathbf{6 a}$ revealed hydroxyl groups at 3560 and $3380 \mathrm{~cm}^{-1}$, and a $\delta$-lactone at $1710 \mathrm{~cm}^{-1}$ as shown in that of carnosol (2), while rosmanol (1a) and epirosmanol (4a) showed a $\gamma$-lactone at 1740 and $1758 \mathrm{~cm}^{-1}$, respectively. Acetylation of $\mathbf{6 a}$ gave triacetyl isorosmanol $(\mathbf{6 b}$, $\mathrm{C}_{26} \mathrm{H}_{32} \mathrm{O}_{8}$ ), which showed three acetyl singlets at $\delta 1.93,2.30$ and 2.31 in the NMR spectrum. Two singlets at $\delta 0.92(3 \mathrm{H})$ and 1.03
$(3 \mathrm{H})$, a doublet at $1.20(6 \mathrm{H}, J=6.6 \mathrm{~Hz})$ and a septet at $3.30(1 \mathrm{H}, J=6.6 \mathrm{~Hz})$ in the spectrum of $6 \mathbf{a}$ suggested the same skeleton as 1a and 2, an abietane skeleton, whose C-ring is aromatized. A doublet at $\delta 5.16(1 \mathrm{H}, J=$ $4.3 \mathrm{~Hz})$ was attributed to the benzylic proton of $\mathrm{C}-7$, onto which lactonization presumably occurred from the C-20 carboxyl group. As a triplet at $\delta 4.34(1 \mathrm{H}, J=4.3 \mathrm{~Hz})$ is coupled with a doublet of the benzylic proton (C-7) at $\delta 5.16$ and a doublet at 1.42 , this triplet was assigned to be the methine proton of C-6 substituted with a hydroxyl group. This was supported by the shift of the triplet at $\delta 4.34$ to $5.42(J=$ $4.3 \mathrm{~Hz}$ ) in the NMR spectrum of the triacetate (6b). The latter doublet at $\delta 1.42$ was attributed to the proton at C-5 and the stereochemical relationship between $\mathrm{H}-5$ and $\mathrm{H}-6$ was revealed to be trans by an NOE experiment and the coupling constant of $4.3 \mathrm{~Hz}$. Consequently, the configuration of $\mathrm{H}-6$ should be $\beta$. This was further supported by the fact that the dihedral angle between $\mathrm{H}-\mathrm{C}_{5}-\mathrm{C}_{6}-\mathrm{H}$ was about $120^{\circ}$ by inspection of the Driding model. On the other hand, in the spectra of rosmanol (1a) and epirosmanol (4a), no coupling was observed between $\mathrm{H}-5$ and $\mathrm{H}-6$ because of the $c i s$ configuration with a dihedral angle of $90^{\circ} .{ }^{1,2)}$

Furthermore, when $\mathrm{H}-5$ at $\delta 1.60$ in the NMR spectrum of the triacetate (6b) was irradiated, NOE was observed with $\mathrm{H}-7$ and not with $\mathrm{H}-6$. These results established $\mathrm{H}-5$ and $\mathrm{H}-7$ to be in the $\alpha$-configuration, and $\mathrm{H}-6$ to be in the $\beta$-configuration.

Therefore the structure of isorosmanol was concluded to be $6 \alpha, 11,12$-trihydroxy-7,10(epoxymethano)abieta-8,11,13-trien-20-one as depicted in structural formula $\mathbf{6 a}$.

The antioxidative activity of the new compounds, epirosmanol (4a) and isorosmanol (6a), was measured by the ferric thiocyanate method in an aqueous ethanolic solution and by the active oxygen method (AOM) in lard, as shown in Figs. 2 and 3, respectively. Both epirosmanol and isorosmanol showed activities comparable with that of BHT in an aqueous solution. When measured in oil 

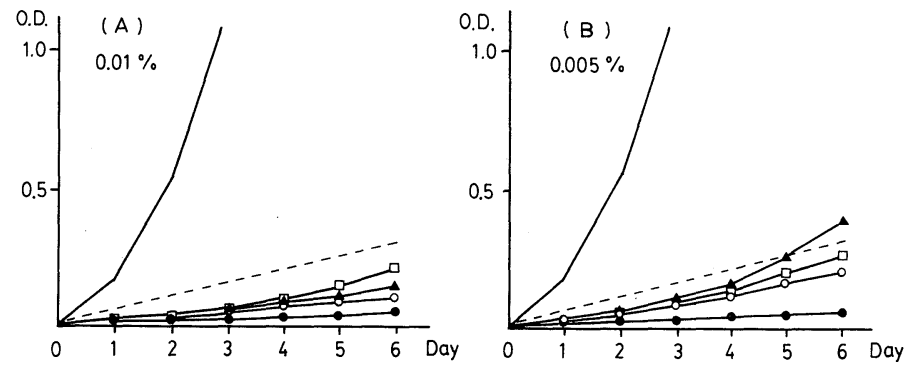

FIG. 2. Antioxidative Activity of Epirosmanol (4a) and Isorosmanol (6a) Measured by the Ferric Thiocyanate Method.

(A) rosmanol, ( $\square$ ) epirosmanol, $(\bigcirc)$ isorosmanol, each concentration at (A) $0.01 \%$ and (B) $0.005 \%$. BHT and (-- ) $\alpha$-tocopherol; (A) and (B) $0.01 \%$. (-) control.
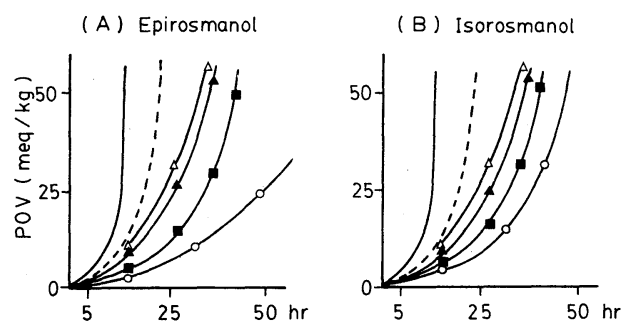

FIG. 3. Antioxidative Activity of (A) Epirosmanol (4a) and (B) Isorosmanol (6a) Measured by the Active Oxygen Method.

$0.005 \%$, (○) $0.01 \%,(\triangle)$ BHT $0.02 \%$, ( $\Delta)$ BHA $0.02 \%,(--) \alpha$-tocopherol $0.02 \%$ and (-) control.

(lard), both compounds showed a stronger activity than those of synthetic antioxidants. By a simple calculation based on the concentration, epirosmanol and isorosmanol as well as rosmanol have antioxidative activities four times stronger than those of BHA and BHT.

\section{EXPERIMENTAL}

Melting points were measured with a Yanagimoto micro melting point apparatus and are uncorrected. UV absorption spectra were determined on a Hitachi 220 spectrophotometer and IR spectra were recorded with a Jasco IR-S. ${ }^{1} \mathrm{H}-\mathrm{NMR}(60 \mathrm{MHz})$ spectra were run on a Hitachi R600 using TMS as an internal standard, and NOE analyses were determined on a JEOL FX-400. MS were obtained on a Shimadzu GCMS-7000S. Optical rotation was measured with a Union PM-101. Column chromatographies were performed using Merck silica gel 60 (70 230 mesh) and Pharmacia Sephadex LH-20, and TLC was done using silica gel GF-254.
Extraction and isolation. The non-volatile fraction of the $n$-hexane extract from dried leaves of rosemary $(3 \mathrm{~kg})$ was separated into four fractions by $\mathrm{pHs}$ as previously mentioned. ${ }^{2)}$ The crude syrup of the weakly acidic fraction was subjected to a silica gel column chromatography with a solution of benzene-acetone $(9: 1, \mathrm{v} / \mathrm{v})$ as the elution solvent to separate into twelve fractions.

Antioxidative assay. Antioxidative activity was measured by the ferric thiocyanate method and active oxygen method as previously mentioned. ${ }^{3)}$

Epirosmanol (4a). The fraction No. $10(1.42 \mathrm{~g})$ was triturated with acetone, and the mixture was filtered. Insoluble crude powder $(205 \mathrm{mg})$ was rechromatographed on a Sephadex LH-20 column using isopropanol as an eluent to afford the compound $4 \mathrm{a}(77 \mathrm{mg})$, which was recrystallized from acetone, $\mathrm{mp} 221.5^{\circ} \mathrm{C}$. Anal. Found: C, 69.13; H, 7.46. Calcd. for $\mathrm{C}_{20} \mathrm{H}_{26} \mathrm{O}_{5}: \mathrm{C}, 69.34 ; \mathrm{H}, 7.57 \%$. $\mathrm{UV} \lambda_{\max }(\mathrm{EtOH}) \mathrm{nm}(\log \varepsilon): 206$ (4.46), 228 (4.16), 290 (3.40). IR $v_{\max }$ (Nujol) $\mathrm{cm}^{-1}: 3530,3350,1758,1440,1295$, $1260,1220,1190,1082,928,880 .{ }^{1} \mathrm{H}-\mathrm{NMR}$ (acetone- $d_{6}$ ) $\delta$ : $0.92(3 \mathrm{H}, \mathrm{s}), 1.04(3 \mathrm{H}, \mathrm{s}), 1.17(6 \mathrm{H}, \mathrm{d}, J=7.2 \mathrm{~Hz}), 1.4 \sim 1.9$ $(5 \mathrm{H}), 2.00(1 \mathrm{H}, \mathrm{s}), 3.0 \sim 3.5(2 \mathrm{H}), 3.74(1 \mathrm{H}), 4.72(2 \mathrm{H}, \mathrm{br}$. s), $7.05(1 \mathrm{H}, \mathrm{s}), 7.34\left(2 \mathrm{H}\right.$, br. s). MS $m / z(\%): 346\left(\mathrm{M}^{+}\right.$, 100), 302 (43), 287 (51), 284 (57), 273 (43), 269 (47), 231 (94), 215 (75).

Triacetyl epirosmanol (4b). To a solution of $90 \mathrm{mg}$ of crude epirosmanol in pyridine $(1 \mathrm{ml})$, acetic anhydride $(1 \mathrm{ml})$ was added and the mixture was allowed to stand overnight at $38^{\circ} \mathrm{C}$. The reaction mixture was poured into cold $1 \mathrm{~N}-\mathrm{HCl}(50 \mathrm{ml})$ and then extracted with benzene. The organic layer was washed with brine, and then dried over anhydrous $\mathrm{MgSO}_{4}$ and concentrated to dryness. The product $(126 \mathrm{mg})$ was purified by column chromatography on silica gel using benzene-acetone $(97: 3, \mathrm{v} / \mathrm{v})$ as the eluent, and by preparative TLC using isopropyl ether as the developing solvent to afford a colorless oil $(34 \mathrm{mg})$. UV $\lambda_{\max }(\mathrm{EtOH}) \mathrm{nm}(\log \varepsilon): 204$ (4.63), 229 sh (3.86). $[\alpha]_{\mathrm{D}}^{25}$ : 
$+68.62^{\circ}\left(c=1.20, \mathrm{CHCl}_{3}\right) . \mathrm{IR} v_{\max }($ film $) \mathrm{cm}^{-1}: 1770,1735$, $1450,1430,1370,1225,1200,1178,1145,1125 .{ }^{1} \mathrm{H}-\mathrm{NMR}$ $\left(\mathrm{CDCl}_{3}\right) \delta: 0.91(3 \mathrm{H}, \mathrm{s}), 1.01(3 \mathrm{H}, \mathrm{s}), 1.16(6 \mathrm{H}, \mathrm{d}, J=$ $7.2 \mathrm{~Hz}), 1.4 \sim 1.8(5 \mathrm{H}), 2.08(1 \mathrm{H}, \mathrm{s}), 2.20(3 \mathrm{H}, \mathrm{s}), 2.28(3 \mathrm{H}$, s), $2.31(3 \mathrm{H}, \mathrm{s}), 2.7 \sim 3.0(2 \mathrm{H}), 4.88(1 \mathrm{H}, \mathrm{d}, J=3.0 \mathrm{~Hz})$, $5.61(1 \mathrm{H}, \mathrm{d}, J=3.0 \mathrm{~Hz}), 7.10(1 \mathrm{H}, \mathrm{s})$. MS $m / z(\%): 472$ $\left(\mathrm{M}^{+}, 6\right), 444$ (2), 430 (3), 402 (6), 388 (8), 328 (27), 300 (12), 284 (100), 215 (57).

Dimethyl epirosmanol (4c). To a solution of $40 \mathrm{mg}$ of crude epirosmanol in dry acetone $(10 \mathrm{ml})$ was added methyl iodide $(1 \mathrm{ml})$ and anhydrous $\mathrm{K}_{2} \mathrm{CO}_{3}(1 \mathrm{~g})$ at $5^{\circ} \mathrm{C}$ with stirring. The mixture was stirred for $4 \mathrm{hr}$ at room temperature. After filtering of the reaction mixture, the filtrate was concentrated in vacuo. The residue was extracted with ether and the organic layer was washed with water, dried over anhydrous $\mathrm{MgSO}_{4}$ and then evaporated to dryness $(34 \mathrm{mg})$. Purification of the product by chromatography on silica gel using benzeneacetone $(97: 3, \mathrm{v} / \mathrm{v})$ as the eluent gave colorless crystals (15 mg), mp 194 $\sim 5^{\circ} \mathrm{C}$. UV $\lambda_{\max }(\mathrm{EtOH}) \mathrm{nm}(\log \varepsilon): 208$ (4.54), $275(3.00) .[\alpha]_{\mathrm{D}}^{25}:+30.0^{\circ}\left(c=0.50, \mathrm{CHCl}_{3}\right)$. IR $v_{\max }$ (film): $3400,1770,1410,1352,1330,1310,1225$, 1173, 1110, 1090, 1040, 1020. ${ }^{1} \mathrm{H}-\mathrm{NMR}\left(\mathrm{CDCl}_{3}\right) \delta: 0.96$ $(3 \mathrm{H}, \mathrm{s}), 1.00(3 \mathrm{H}, \mathrm{s}), 1.19(6 \mathrm{H}, \mathrm{d}, J=7.2 \mathrm{~Hz}), 1.4 \sim 1.8$ $(5 \mathrm{H}), 1.94(1 \mathrm{H}, \mathrm{s}), 2.36(1 \mathrm{H}$, br. s), $3.0 \sim 3.5(2 \mathrm{H}, \mathrm{m})$, $3.80(3 \mathrm{H}, \mathrm{s}), 3.82(3 \mathrm{H}, \mathrm{s}), 4.5 \sim 4.8(2 \mathrm{H}, \mathrm{m}), 7.27(1 \mathrm{H}, \mathrm{s})$. MS $m / z(\%): 374 \mathrm{f}\left(\mathrm{M}^{+}, 100\right), 330$ (14), 315 (52), 301 (66), 287 (17), 259 (37).

Oxidation of dimethyl epirosmanol. To a solution of dimethyl epirosmanol $(\mathbf{4 c}, 10 \mathrm{mg})$ in dry ether $(3 \mathrm{ml})$, active manganese dioxide $(100 \mathrm{mg})$ was added. The mixture was stirred at room temperature for $2 \mathrm{hr}$. After removing the oxidative reagent by filtration, the filtrate was concentrated to afford a keto lactone $(5,6 \mathrm{mg})$. Recrystallization from isopropyl ether gave colorless prisms, $\mathrm{mp} 120^{\circ} \mathrm{C}$. The spectral data of IR, NMR and MS were identical in all respects with dimethyl rosmanol oxide. ${ }^{2)}$

Reduction of dimethyl epirosmanol oxide. To a solution of the above oxide $(5,22 \mathrm{mg})$ in methanol $(15 \mathrm{ml})$ was added portionwise $\mathrm{NaBH}_{4}(34 \mathrm{mg})$ at $5 \sim 10^{\circ} \mathrm{C}$, and the mixture was stirred for $1 \mathrm{hr}$. After evaporating the methanol, $2 \mathrm{~N}-\mathrm{HCl}$ was added to the residue, which was then extracted with benzene. The concentrated products $(17 \mathrm{mg})$ were identified with the $7 \alpha$-hydroxy isomer (1c) and the $7 \beta$-hydroxy isomer $(\mathbf{4 c})$ at a ratio of 15 to 85 , as determined by GC-MS.

Isorosmanol (6a). The fraction $9(572 \mathrm{mg})$ was rechromatographed on a silica gel column using benzeneacetone $(6: 1, \mathrm{v} / \mathrm{v})$ as the eluent to afford a white powder $(110 \mathrm{mg})$. This fraction was purified by rechromatography on a Sephadex LH-20 column, which was eluted with isopropanol to give pure colorless crystals $(50 \mathrm{mg}), \mathrm{mp}$ $227^{\circ} \mathrm{C}$. Anal. Found: C, 69.03; H, 7.58. Calcd. for $\mathrm{C}_{20} \mathrm{H}_{26} \mathrm{O}_{5}$ : C, 69.34; $\mathrm{H}, 7.57 \%$. UV $\lambda_{\text {max }}(\mathrm{EtOH}) \mathrm{nm}(\log \varepsilon)$ : 207 (4.44), $227 \mathrm{sh}$ (4.02), 286 (3.23). IR $v_{\max }$ (Nujol) $\mathrm{cm}^{-1}$ : $3560,3380,1710,1450,1380,1368,1340,1265,1015,980$. ${ }^{1} \mathrm{H}-\mathrm{NMR}$ (acetone- $\left.d_{6}\right) \delta: 0.92(3 \mathrm{H}, \mathrm{s}), 1.03(3 \mathrm{H}, \mathrm{s}), 1.20$ $(6 \mathrm{H}, \mathrm{d}, J=6.6 \mathrm{~Hz}), 1.42(1 \mathrm{H}, \mathrm{d}, J=4.3 \mathrm{~Hz}), 1.4 \sim 2.8(5 \mathrm{H})$, $3.30(2 \mathrm{H}), 4.34\left(2 \mathrm{H}, \mathrm{D}_{2} \mathrm{O}\right.$ addition $\left.1 \mathrm{H}, \mathrm{t}, J=4.3 \mathrm{~Hz}\right), 5.16$ $(1 \mathrm{H}, \mathrm{d}, J=4.3 \mathrm{~Hz}), 6.81(1 \mathrm{H}, \mathrm{s}), 7.4(2 \mathrm{H}) . \mathrm{MS} m / z(\%): 346$ $\left(\mathrm{M}^{+}, 100\right), 302$ (77), 300 (71), 273 (40), 257 (29), 245 (35), 233 (50), 232 (57), 231 (64), 219 (45), 205 (44).

Triacetyl isorosmanol (6b). Acetylation of isorosmanol (6a, $20 \mathrm{mg}$ ) was carried out as mentioned above to afford a colorless oil $(21 \mathrm{mg})$. UV $\lambda_{\max }(\mathrm{EtOH}) \mathrm{nm}(\log \varepsilon): 203$ (4.60), $228 \mathrm{sh}(3.84) .[\alpha]_{\mathrm{D}}^{25}:+42.36^{\circ}\left(c=1.02, \mathrm{CHCl}_{3}\right)$, IR $v_{\max }($ film $) \mathrm{cm}^{-1} ; 1760,1716,1455,1435,1373,1275$, $1230,1200,1180,1140,1040,1025 .{ }^{1} \mathrm{H}-\mathrm{NMR}\left(\mathrm{CDCl}_{3}\right) \delta$ : $0.90(3 \mathrm{H}, \mathrm{s}), 0.97(3 \mathrm{H}, \mathrm{s}), 1.16(3 \mathrm{H}, \mathrm{d}, J=7.2 \mathrm{~Hz}), 1.18$ $(3 \mathrm{H}, \mathrm{d}, J=7.2 \mathrm{~Hz}), 1.4 \sim 2.2(5 \mathrm{H}), 1.60(1 \mathrm{H}, \mathrm{d}, J=4.3 \mathrm{~Hz})$, $1.93(3 \mathrm{H}, \mathrm{s}), 2.30(3 \mathrm{H}, \mathrm{s}), 2.31(3 \mathrm{H}, \mathrm{s}), 2.4 \sim 3.2(2 \mathrm{H}, \mathrm{m})$, $5.42(1 \mathrm{H}, \mathrm{t}, J=4.3 \mathrm{~Hz}), 5.52(1 \mathrm{H}, \mathrm{d}, J=4.3 \mathrm{~Hz}), 7.07(1 \mathrm{H}$, s). MS $m / z(\%): 472\left(\mathrm{M}^{+}, 11\right), 430(7), 388(100), 346(67)$, 342 (33), 300 (47), 284 (67), 215 (39).

Acknowledgments. We are grateful to Dr. M. Kido, Otsuka Pharmaceutical Co., Ltd., for X-ray analysis and to Dr. H. Seto and Dr. H. Nakayama, the University of Tokyo, for measuring NOE on a $400 \mathrm{MHz}{ }^{1} \mathrm{H}-\mathrm{NMR}$. We are also indebted to Dr. T. Yoshida and Dr. S. Muraki, Takasago Perfumery Co., Ltd., for supplying rosemary and technical co-operation.

\section{REFERENCES}

1) N. Nakatani and R. Inatani, Agric. Biol. Chem., 45, 2385 (1981).

2) R. Inatani, N. Nakatani, H. Fuwa and H. Seto, Agric. Biol. Chem., 46, 1661 (1982).

3) R. Inatani, N. Nakatani and H. Fuwa, Agric. Biol. Chem., 47, 521 (1983).

4) N. Nakatani and R. Inatani, Agric. Biol. Chem., 47, 353 (1983).

5) S. S. Chang, B. O. Matijasevic, O. A. L. Hsieh and C. L. Huang, J. Food Sci., 42, 1102 (1977).

6) R. E. Hayes, G. N. Bookwalter and E. B. Bagley, $J$. Food Sci., 42, 1527 (1977).

7) T. Osawa and M. Namiki, Agric. Biol. Chem., 45, 735 (1981).

8) J. W. Wu, M-H. Lee, C-T. Ho and S. S. Chang, $J$. Am. Oil Chemists' Soc., 59, 339 (1982).

9) T. Aoyama, Y. Nakakita, M. Nakagawa and H. Sakai, Agric. Biol. Chem., 46, 2369 (1982).

10) D. E. Pratt, C. D. Pietro, W. L. Porter and J. W. Giffee, J. Food Sci., 47, 24 (1982). 